\title{
Penerapan Model Pembelajaran Learning Cycle 5E yang Terintegrasi dengan Metode Problem Solving
}

\section{The Application of Learning Cycle 5E Model which was Integrated with Problem Solving Method}

\author{
Nurul Ilmi ${ }^{1 *}$, Pince Salempa ${ }^{1)}$, Sumiati Side ${ }^{1)}$ \\ ${ }^{1}$ Jurusan Kimia/ Program Studi Pendidikan Kimia, Universitas Negeri Makassar
}

Received $6^{\text {th }}$ August 2019 / Accepted 20 th August 2019

\begin{abstract}
ABSTRAK
Penelitian ini adalah penelitian tindakan kelas yang bertujuan untuk menemukan langkah-langkah penerapan model pembelajaran learning cycle 5E yang terintegrasi dengan metode problem solving sehingga dapat meningkatkan aktivitas belajar dan kemampuan pemecahan masalah peserta didik pada materi titrasi dan kesetimbangan larutan. Penelitian ini berlangsung dalam dua siklus, masing-masing terdiri dari empat tahap yaitu perencanaan, pelaksanaan tindakan, observasi, dan evaluasi. Pengumpulan data dilakukan dengan menggunakan lembar observasi dan tes kemampuan pemecahan masalah di setiap akhir siklus. Data yang diperoleh dianalisis secara deskriptif dengan memaparkan gambaran umum tentang data yang diperoleh selama penelitian. Hasil penelitian menunjukkan bahwa aktivitas dan kemampuan pemecahan masalah peserta didik meningkat setelah menerapkan model pembelajaran learning cycle $5 E$ dengan langkah-langkah fase engagement, fase exploration, fase explanation, fase elaboration yang terintegrasi dengan metode problem solving, dan fase evaluation. Hasil analisis data rata-rata aktivitas belajar peserta didik terjadi peningkatan yaitu dari $72.0 \%$ pada siklus I menjadi $76.3 \%$ pada siklus II. Sedangkan pada persentase rata-rata kemampuan pemecahan masalah peserta didik juga terjadi peningkatan yaitu dari 78.3\% pada siklus I meningkat menjadi $84.8 \%$ pada siklus selanjutnya.
\end{abstract}

Kata Kunci: learning cycle 5E, problem solving, aktivitas belajar, kemampuan pemecahan masalah

\section{ABSTRACT}

This research was a classroom action research that aims to find the steps of applying the learning cycle 5E model which was integrated with the problem solving method so that improve learning activities and problem solving abilities of the students on titration material and the solution equilibrium. This research took place in two cycles, each consists four stages, namely planning, implementing actions, observing, and evaluating. Data collection was performed by using observation sheets and problem solving ability tests at the end of each cycle. The data obtained were analyzed descriptively by describing a general description of the data during the study. The results showed the activity and problem solving ability of students increased after applying the learning cycle $5 E$ model with steps of the engagement phase, exploration

*Korespondensi:

email:menurulilmi@gmail.com 
phase, explanation phase, elaboration phase which was integrated with the problem solving method, and evaluation phase. The results showed the average of students' learning activities increased from $72.0 \%$ in the first cycle to $76.3 \%$ in the second cycle, while the average of students' problem solving abilities increased from $78.3 \%$ in the first cycle to $84.8 \%$ in the next cycle.

Keywords: learning cycle 5E, problem solving, learning activity, problem solving ability

\section{PENDAHULUAN}

Perubahan paradigma pembelajaran dengan menerapkan Kurikulum 2013 merupakan hasil revisi dari Kurikulum Tingkat Satuan Pendidikan (KTSP). Orientasi pembelajaran yang semula berpusat pada guru (teacher-centered) beralih berpusat pada peserta didik (student-centered). Metodologi yang semula lebih banyak bersifat tekstual berubah menjadi kontekstual. Semua perubahan tersebut dimaksudkan untuk memperbaiki pendidikan baik dari segi proses maupun dari segi hasil pendidikan.

Hasil observasi yang dilakukan oleh peneliti di SMA Negeri 3 Makassar menunjukkan bahwa model pembelajaran yang diterapkan sesuai dengan yang dianjurkan oleh Kurikulum 2013. Observasi proses pembelajaran dilakukan di kelas XI MIA 1 berdasarkan penuturan dari guru pelajaran kimia kelas tersebut bahwa kelas tersebut memiliki beberapa permasalahan. Permasalahan tersebut berupa aktivitas peserta didik yang belum optimal. Hal tersebut terlihat dari umpan balik yang diberikan oleh peserta didik kepada guru yang masih kurang. Selain itu kemampuan pemecahan masalah masih sangat rendah. Hanya beberapa orang yang dapat menyelesaikan soalsoal berbasis problem solving. Dilihat dari cara menjawab soal peserta didik yang tidak menggunakan langkah-langkah terencana, cenderung menjawab dengan cara instan.

Berdasarkan permasalahan di atas maka perlu adanya penerapan model pembelajaran yang dapat meningkatkan aktivitas belajar dan kemampuan pemecahan masalah peserta didik. Salah satu model pembelajaran yang memberikan kesempatan kepada peserta didik untuk mengoptimalkan aktivitas dan mengembangkan daya nalar adalah model pembelajaran learning cycle. Menurut Karpus dan Their dalam Sudarjo (2016) Learning Cycle adalah suatu model pembelajaran yang berpusat pada pembelajar (student centered). Penelitian yang dilakukan oleh Auliah (2009) yang menyimpulkan bahwa penerapan pembelajaran learning cycle dapat meningkatkan aktivitas peserta didik.

Namun menurut Permadi (2017) model pembelajaran Learning Cycle $5 E$ memiliki kelemahan salah satunya adalah menuntut kesungguhan dan kreatifitas guru dalam merangsang dan melaksanakan pembelajaran. Untuk meningkatkan kemampuan peserta didik dalam memecahkan masalah dan mengatasi kelemahan tersebut dengan menggunakan metode yang tepat. Dalam materi perhitungan khususnya materi titrasi dan kesetimbangan larutan metode problem solving dianggap dapat mengatasi kelemahan dari model learning cycle $5 E$.

Menurut Nasution (2008) metode pembelajaran problem solving merupakan proses dimana peserta didik mengkonstruksi sendiri konsep yang telah dipelajarinya lebih 
dahulu yang digunakannya untuk memecahkan masalah baru. Metode tersebut merupakan metode yang dilakukan untuk melatih para peserta didik dalam menghadapi berbagai masalah yang dapat diselesaikan secara mandiri ataupun bersama-sama, sehingga peserta didik terlatih untuk berpikir dan bertindak secara realistis. Metode tersebut juga banyak menumbuhkan aktivitas belajar secara individual maupun kelompok. Hampir setiap langkah menuntut keaktifan belajar peserta didik, sedangkan peranan guru lebih banyak sebagai pemberi stimulasi, pembimbing kegiatan, dan memberikan arahan mengenai apa yang harus dilakukan peserta didik.

Pada metode pemecahan masalah, peserta didik dituntut untuk mengembangkan keterampilan proses sains dalam melakukan analisis masalah serta mencari hubungan antara data yang ada dengan konsep awal yang dimiliki sehingga dapat menemukan pemecahan masalah yang dicari (Hasanah, 2015). Untuk melihat kemampuan pemecahan masalah peserta didik dapat ditinjau pada empat aspek yakni memahami masalah, merencanakan pemecahannya, menyelesaikan masalah sesuai rencana, dan memeriksa kembali pemecahan masalah. Hal tersebut sejalan dengan penelitian yang dilakukan oleh Sopian (2017) dimana peningkatan kemampuan proses pemecahan masalah pada kelas yang menggunakan model Creative Problem Solving adalah sedang.

Berdasarkan latar belakang di atas, maka pelaksanaan metode problem solving yang diintegrasikan pada model pembelajaran learning cycle $5 E$ diharapkan dapat meningkatkan aktivitas belajar serta menunjang dalam peningkatan kemampuan pemecahan masalah peserta didik. Sehingga peneliti melakukan penelitian dengan judul "Penerapan Model Pembelajaran Learning Cycle $5 E$ yang Terintegrasi dengan Metode Problem Solving untuk Meningkatkan Aktivitas Belajar dan Kemampuan Pemecahan Masalah Peserta Didik Kelas XI MIA 1 SMA Negeri 3 Makassar (Pokok Materi Pada Titrasi dan Kesetimbangan Larutan).”

\section{METODE}

Penelitian ini termasuk jenis penelitian tindakan kelas (PTK) yang secara umum bertujuan meningkatkan dan memperbaiki proses kegiatan pembelajaran. Desain penelitian ini mengacu pada model penelitian tindakan kelas spiral dari Kemmis dan Taggart, terdapat empat tahap dalam siklus penelitian kelas yaitu tahap perencanaan, tindakan, observasi, dan refleksi.

Subjek penelitian dalam penelitian ini adalah peserta didik kelas XI MIA 1 SMA Negeri 3 Makassar 2017/2018 yang terdiri dari 39 peserta didik. Subjek penelitian ini ditentukan setelah melakukan obervasi tentang aktivitas belajar dan kemampuan pemecahan masalah peserta didik. Waktu pembelajaran dilaksanakan sebanyak delapan kali pertemuan (4 minggu) yaitu Bulan April - Mei 2018.

Instrumen yang digunakan dalam penelitian ini meliputi lembar observasi aktivitas peserta didik dan tes kemampuan pemecahan masalah. Lembar observasi aktivitas digunakan untuk mengetahui keterlaksanaan proses pembelajaran berlangsung dengan model pembelajaran learning cycle $5 E$ yang terintegrasi dengan metode problem solving. Pada tes kemampuan pemecahan masalah diberikan tes berbentuk uraian untuk 
mengukur kemampuan pemecahan masalah peserta didik peserta didik pada materi pokok titrasi dan kesetimbangan larutan.

Teknik analisis aktivitas belajar peserta didik menggunakan analisis deskriptif. Analisis deskriptif memberikan gambaran umum tentang data yang diperoleh selama penelitian. Untuk keperluan analisis data akhir aktivitas belajar peserta didik, maka frekuensi pertemuan pertama dan kedua pada siklus pertama dicari persentase rata-rata setiap aktivitasnya kemudian digeneralisasikan. Angka presentase yang diperoleh kemudian akan dikelompokkan berdasarkan pada pedoman pengkategorian aktivitas belajar. Analisis data pada kemampuan pemecahan masalah dapat dilihat berdasarkan kemampuan peserta didik menjawab soal berdasarkan aspek mengidentifikasi masalah, merencanakan penyelesaian masalah, menyelesaikan masalah, dan mengecek kembali hasil yang diperoleh dan menuliskan kesimpulan. Hasil rekapitulasi nilai kemampuan pemecahan masalah kemudian akan dikelompokkan berdasarkan pada pedoman kemampuan pemecahan masalah.

\section{HASIL DAN PEMBAHASAN}

\section{Hasil Penelitian}

Tabel 1. Perbandingan Aktivitas Belajar Peserta Didik Berdasarkan Model Pembelajaran Learning Cycle 5E Siklus I dan II

\begin{tabular}{clcc}
\hline No. & \multicolumn{2}{c}{ Fase } & \multicolumn{2}{c}{ Tindakan } \\
\cline { 3 - 4 } & & Siklus I (\%) & Siklus II (\%) \\
\hline 1. & Engangement & 89.7 & 97.4 \\
2. & Exploration & 84.6 & 89.7 \\
3. & Explaination & 71.8 & 83.3 \\
4. & Elaboration & 71.8 & 82.1 \\
5. & Evaluation & 74.4 & 84.6 \\
\hline
\end{tabular}

Adapun diagram perbandingan persentase aktivitas belajar peserta didik berdasarkan model pembelajaran learning cycle $5 E$ siklus I dan II dapat diliat pada Gambar 1.

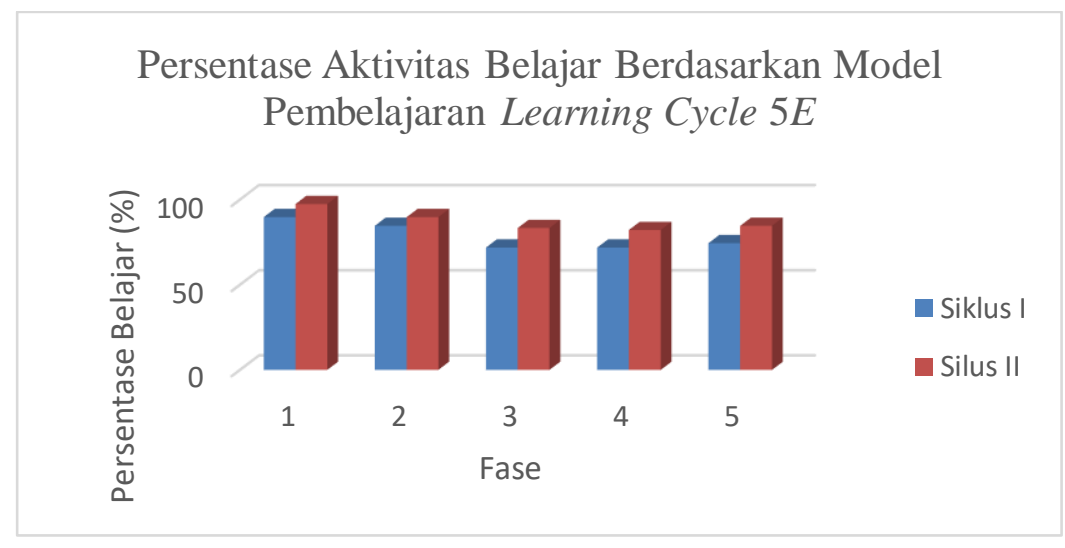

Gambar 1. Diagram Aktivitas Belajar Model Pembelajaran Learning Cycle 5E Siklus I dan II 
Berdasarkan data yang diperoleh dari tindakan kelas dapat dilihat peningkatan hasil tes keterampilan pemecahan masalah peserta didik siklus I dan II dalam Tabel 2.

Tabel 2. Perbandingan Hasil Tes Kemampuan Pemecahan Masalah Siklus I dan II

\begin{tabular}{rlcc}
\hline \multirow{2}{*}{ No. } & \multirow{2}{*}{ Indikator Pemecahan Masalah } & \multicolumn{2}{c}{ Tindakan } \\
\cline { 3 - 4 } & & Siklus I (\%) & Siklus II (\%) \\
\hline 1. & Mengidentifikasi masalah & 100 & 100 \\
2. & Merencanakan penyelesaian masalah & 91,7 & 94,87 \\
3. & Menyelesaikan masalah & 58,63 & 80,17 \\
4. & Mengecek kembali hasil yang & 54,9 & 80,00 \\
\hline
\end{tabular}

Adapun diagram perbandingan hasil tes keterampilan pemecahan masalah peserta didik siklus I dan II terdapat pada Gambar 2.

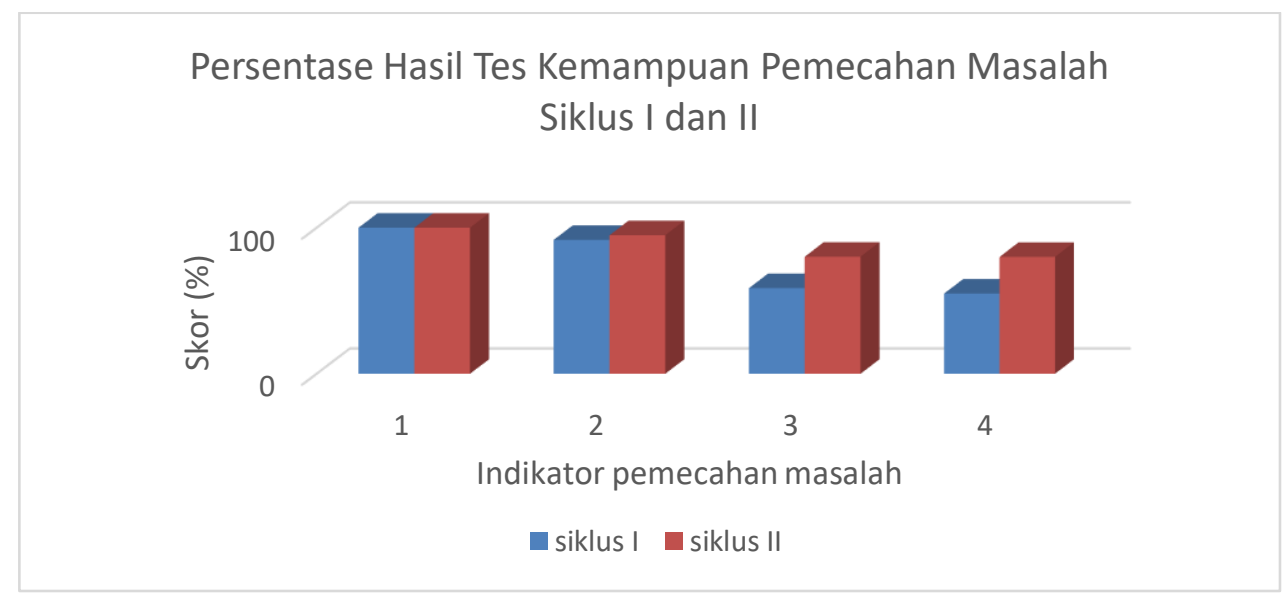

Gambar 2. Diagram Persentase Hasil Tes Kemampuan Pemecahan Masalah Siklus I dan II

\section{PEMBAHASAN}

Kegiatan pembelajaran dilaksanakan dalam dua siklus dengan setiap kali siklus dilaksanakan sebanyak empat kali pertemuan. Pada siklus pertama membahas materi titrasi dan pada siklus kedua membahas materi kesetimbangan larutan. Guru mengawali kegiatan pembelajaran dengan berdoa, kemudian mempresensi peserta didik, dan menanyakan kondisi fisik peserta didik. Guru memberikan motivasi agar peserta didik benar-benar siap fisik dan mental sehingga dapat mengikuti kegiatan pembelajaran dengan baik. Sebagai kegiatan motivasi, guru menyampaikan indikator atau tujuan yang hendak dicapai dari pelaksanaan pembelajaran dengan memberikan apersepsi yang berkaitan dengan materi pelajaran yang akan dilaksanakan.

Fase Engagement guru mengawali pembelajaran dengan menggali pengetahuan awal peserta didik dengan mengajukan pertanyaan tentang materi titrasi dan kesetimbangan larutan. Fase ini juga bertujuan membangkitkan minat dan 
keingintahuan peserta didik tentang materi pokok bahasan. Fase awal ini mendapat tanggapan positif dari peserta didik ketika peserta didik menjawab pertanyaan dari guru. Guru menggali pengetahuan awal peserta didik dengan mengajukan pertanyaan, contohnya "Apa yang anda ketahui tentang klasifikasi asam dan basa?" Jawaban dari masing-masing peserta didik beragaam. Pertanyaan kemudian dilanjutkan dengan meminta peserta didik memberikan contoh larutan asam dan basa. Pertanyaan selanjutnya adalah apa yang terjadi ketika larutan asam dicampurkan dengan larutan basa? Jawaban peserta didik juga beragam. Hampir seluruh peserta didik berpartisipasi aktif pada tahap ini. Hal ini mengindikasikan bahwa pada fase ini minat dan keingintahuan peserta didik sangat tinggi. Minat peserta didik pada fase awal ini sangat membantu dalam berjalannya pembelajaran pada fase berikutnya.

Fase Exploration peserta didik diberi kesempatan untuk bekerja sama dalam kelompok-kelompok kecil. Guru membagi kelompok yang terdiri dari empat sampai lima orang peserta didik. Guru lalu membagikan bahan ajar sebagai bahan diskusi kelompok dan meminta siswa untuk menjawab pertanyaan yang ada dengan berdiskusi. Guru bertugas membimbing dan sebagai fasilitator saat berjalannya diskusi. Guru juga harus selalu memantau proses diskusi peserta didik.

Fase Explanation guru mendorong peserta didik untuk menjelaskan konsep dengan kalimat sendiri-sendiri, serta meminta bukti dari penjelasan para peserta didik. Fase explanation ini guru meminta peserta didik untuk mempresentasikan hasil diskusi beberapa kelompok. Kelompok yang ditunjuk guru mempresentasikan hasil diskusi kelompoknya. Guru bertindak sebagai moderator bertugas untuk mengarahkan agar diskusi berjalan sesuai dengan pokok bahasan. Pada fase ini, guru juga memberikan kesempatan kepada kelompok lain untuk bertanya jika ada yang tidak jelas.

Fase Elaboration peserta didik menerapkan konsep dan keterampilan dalam situasi baru. Penerapan pada fase elaboration guru mengajukan permasalahan baru berupa soal latihan yang terdapat pada Lembar Kerja Peserta Didik (LKPD). Peserta didik mengerjakan sesuai dengan hasil diskusi dan presentasi. Pada fase ini peneliti mengintegrasikannya dengan metode problem solving. Sehingga dalam menjawab soal LKPD peserta didik akan mengasah kemampuan pemecahan masalahannya. Adapun tahap-tahap metode problem solving pada penelitian ini yaitu: (1) mengidentifikasi masalah, (2) merencakan penyelesaian masalah, (3) menyelesaikan masalah, dan (4) mengecek kembali hasil yang diperoleh dan menuliskan kesimpulan.

Fase Evaluate guru memberikan tes untuk mengukur sejauh mana pemahaman peserta didik pada materi yang telah diajarkan. Sebagai kegiatan penutup guru memberikan penguatan, penegasan tentang konsep dari simpulan pada materi yang diajarkan.

Hasil analisis aktivitas belajar peserta didik pada proses pembelajaran siklus I dan siklus II yang dilakukan dengan penerapan integrasi metode problem solving pada model pembelajaran learning cycle $5 E$ pada pembelajaran kimia pokok bahasan titrasi dan kesetimbangan larutan menjadi lebih baik. Artinya terjadi peningkatan nlai rata-rata peserta didik dari segi aktivitas dan kemampuan pemecahan masalah pada siklus II. Dari hasil analisis data rata-rata aktivitas belajar peserta didik terjadi peningkatan yaitu 
dari $72.0 \%$ pada siklus I menjadi $76.3 \%$ pada siklus II. Sedangkan pada persentase ratarata kemampuan pemecahan masalah peserta didik juga terjadi peningkatan yaitu dari $78.3 \%$ pada siklus I meningkat menjadi $84.8 \%$ pada siklus 2 . Ini berarti bahwa proses pembelajaran dengan menggunakan integrasi metode problem solving pada model pembelajaran learning cycle $5 E$ telah dilaksanakan dengan baik. Hal ini ditunjukkan dengan adanya peningkatan aktivitas belajar peserta didik pada waktu melakukan kegiatan integrasi metode problem solving pada model pembelajaran learning cycle $5 E$ pada pokok bahasan kesetimbangan larutan.

Persentase keseluruhan aktivitas baik teoritis maupun berdasarkan model pembelajaran mengalami peningkatan dan berkategori minimal aktif. Sehingga nilai tes peserta didik mengalami peningkatan yang cukup baik. Hasil penelitian ini sejalan dengan penelitian yang telah dilakukan oleh Auliah (2009) dan Palennari (2010) yang menunjukkan terdapat peningkatan aktivitas belajar peserta didik dengan menggunakan model pembelajaran learning cycle. Peningkatan tersebut didasarkan karena setiap aktivitas dalam learning cycle $5 E$ berpusat pada peserta didik (student-centered) sehingga pemerolehan konsep berorentasi pada keterlibatan peserta didik secara aktif dan langsung. Proses pembelajaran demikian akan lebih bermakna, menghindarkan peserta didik dari cara belajar tradisional yang cenderung menghafal, dan menjadikan skema dalam diri peserta didik yang setiap saat dapat diorganisasi oleh peserta didik untuk menyelesaikan masalah-masalah yang dihadapi (Sutardi, 2015).

Teknik yang dilakukan guru (peneliti) sehingga aktivitas dapat meningkat adalah (1) guru melakukan pembimbingan dan pendampingan khusus pada peserta didik, baik kelompok maupun individu yang mengalami kesulitan belajar, (2) pada fase tertentu yang dianggap membutuhkan waktu yang lama, maka diberikan strategi khusus. Salah satu contoh, peserta didik pada umumnya kesulitan dalam memahami setiap indikator keterampilan pemecahan masalah sehingga guru memperlihatkan caranya, lalu setiap anggota kelompok mengikuti apa yang dilakukan oleh guru. Hal ini senada senada menurut Polya (Tawil dan Liliasari, 2013) bahwa pada tahap memecahkan masalah, guru dapat membantu peserta didik apabila mengalami kesulitan. Bantuan ini dapat berupa pertanyaan-pertanyaan, memberikan trik, petunjuk, dan analogi yang berguna untuk menemukan jalan keluarnya.

Berdasarkan hasil penilaian LKPD, dapat diketahui bahwa hasilnya mengalami peningkatan dari siklus I ke siklus II. Adapun strategi yang dilakukan guru sehingga hasil LKPD meningkat, di antaranya (1) memberikan bimbingan yang lebih intensif kepada kelompok yang mengalami kesulitan belajar, dan (2) mengarahkan peserta didik yang memiliki kemampuan lebih untuk membantu rekan kelompoknya yang belum memahami materi yang dipelajari.

Dalam menyelesaikan pemecahan masalah diperlukan aturan kompleks dan aturan tingkat tinggi yang dapat dicapai setelah menguasai aturan dan konsep terdefinisi. Demikian pula aturan dan konsep terdefinisi dapat dikuasai jika ditunjang oleh pemahaman konsep konkrit. Setelah itu untuk memahami konsep konkrit diperlukan keterampilan dalam memecahkan suatu permasalahan (Zulfianti, 2016). Hasil tes kemampuan pemecahan masalah setiap peserta didik berbeda-beda. Perbedaan ini 
disebabkan oleh beberapa faktor, diantaranya minat untuk belajar kimia cenderung fluktuatif, kurangnya dasar pelajaran kimia, dan terdapat peserta didik yang tidak siap saat mengikuti tes kemampuan pemecahan masalah. Hasil tes kemampuan pemecahan masalah mengalami peningkatan disetiap indikatornya. Berikut rincian pembahasan disetiap indikator pemecahan masalah pada tes akhir tiap siklus.

Indikator mengidentifikasi masalah, umumnya peserta didik sudah terbiasa menuliskan apa yang diketahui dan ditanyakan pada soal, hal tersebut terlihat dari persentase pada siklus I khususnya indikator mengidentifikasi masalah mencapai $100 \%$. Hal yang menjadi kendala bagi peserta didik pada tahap ini adalah pada latihan soal LKPD terdapat beberapa peserta didik yang malas menuliskan informasi yang diberikan pada soal. Namun setelah diberikan penjelasan pada setiap pertemuan mereka menjadi terbiasa dalam membuat informasi yang dibutuhkan soal. Kemampuan peserta didik dalam memahami masalah pada tes akhir tetap yaitu dengan persentase $100 \%$. Contoh jawaban peserta didik pada tahap ini dapat dilihat pada Gambar 3.

Dik: $\mathrm{KSPAg}_{2} \mathrm{CrO}_{4}=2,4 \cdot 10^{-12}$
Dit: a. Kelarutan dalam AgNo $0,1 \mathrm{M}$
b. Kelarutan $\mathrm{K}_{2} \mathrm{CrO}_{4} \mathrm{O}, 1 \mathrm{M}$

Gambar 3. Contoh jawaban indikator mengidentifikasi masalah

Indikator merencanakan penyelesaian masalah pada siklus I mendapatkan persentase $87,82 \%$. Kesulitan pada tahap ini yaitu dalam mengubah informasi yang ada pada tahap mengidentifikasi masalah menjadi persamaan-persamaan untuk mempermudah mereka dalam menemukan solusi dengan menggunakan strategi yang telah dipilih. Siswa beranggapan bahwa menuliskan rencana penyelesaian masalah merupakan pekerjaan yang berat. Setelah diberikan penjelasan dan latihan soal setiap pertemuan mereka menjadi terbiasa. Sehingga pada siklus II indikator ini mengalami peningkatan persentase menjadi $94,87 \%$. Contoh jawaban pada indikator ini dapat dilihat pada Gambar 4.

$$
k s p=\left[\mathrm{Mg}^{2+}\right]\left[\mathrm{OH}^{-}\right]^{2}
$$

Gambar 4. Contoh jawaban indikator merencakan penyelesaian masalah

Indikator menyelesaikan masalah menjadi persentase indikator terendah pada siklus I, hanya 58,63\%. Pada tahap ini peserta didik diharapkan mampu menggunakan strategi pemecahan yang dipilih dengan konsisten sampai menemukan solusi yang diminta. Hal yang menjadi kendala peserta didik adalah kurang teliti dan sering mengalami kesalahan dalam perhitungan. Namun setelah diberikan penjelasan saat mengerjakan soal LKPD, peserta didik menjadi terbiasa untuk menuliskan penyelesaian masalah dengan teliti termasuk dalam melakukan perhitungan. Sehingga pada siklus II persentase menyelesaikan masalah mengalami peningkatan menjadi 80,17\%. Contoh jawaban pada indikator ini dapat dilihat pada Gambar 5. 


\begin{tabular}{|c|c|c|}
\hline$\left[H^{+}\right]:$ & Asam & $p H=-\log [H+]$ \\
\hline & Garnm & $=-20 \mathrm{~g} 2 \cdot \mathrm{w}^{-5}$ \\
\hline$=$ & $0,75 \mathrm{mmas} \cdot 2 \cdot \omega^{-5}$ & $=5-\log 2$ \\
\hline & $0,75 \mathrm{mmo}$, & $u$ \\
\hline$=$ & $2 \cdot w^{-5}$ & \\
\hline
\end{tabular}

Gambar 5. Contoh jawaban indikator menyelesaikan masalah

Indikator pemecahan masalah terakhir adalah mengecek kembali hasil yang diperoleh dan menuliskan kesimpulan. Dari hasil tes yang diberikan, banyak peserta didik tidak mengecek kembali hasil yang diperoleh dan menuliskan kesimpulan pekerjaan mereka. Hal ini disebabkan peserta didik menganggap bahwa menuliskan interpretasi hasil pada lembar jawaban mereka hanya membuang-buang waktu. Persentase indikator mengecek kembali hasil yang diperoleh dan menuliskan kesimpulan mengalami peningkatan dari $54,9 \%$ pada siklus I menjadi $80,00 \%$ pada siklus II. Contoh jawaban dari indikator mengecek kembali hasil yang diperoleh dan menuliskan kesimpulan dapat dilihat pada Gambar 6.

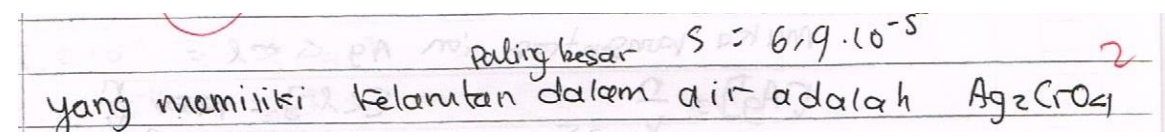

Gambar 6. Contoh jawaban indikator mengecek kembali hasil yang diperoleh dan menuliskan kesimpulan

Hasil penelitian mengalami peningkatan dari siklus I ke siklus II. Upaya yang dilakukan oleh guru adalah menciptakan suasana belajar yang menyenangkan mulai dari awal hingga akhir pembelajaran, dan memberikan kegiatan yang menarik seperti demonstrasi pada pokok bahasan titrasi. Guru juga memotivasi peserta didik agar senantiasa aktif dalam pembelajaran.

Secara umum hasil tes keterampilan pemecahan masalah mengalami peningkatan skor rata-rata dari siklus I ke siklus II. Strategi yang dilakukan pendidik agar hasil dapat meningkat adalah memberikan bimbingan kepada peserta didik yang mengalami kesulitan ketika mengerjakan soal LKPD dan memberikan soal latihan kepada peserta didik untuk dikerjakan di rumah. Hal tersebut sejalan dengan pendapat Sri (Tawil dan Liliasari, 2013) yang menyatakan bahwa peserta didik dihadapkan masalah-masalah, kemudian mereka memecahkan sendiri sampai mendapatkan pemecahannya/ kesimpulannya, sehingga peserta didik dibiasakan memecahkan masalah. Hal inilah yang mendasari peningkatan kemampuan pemecahan masalah peserta didik mengalami peningkatkan.

\section{KESIMPULAN}

Berdasarkan hasil penelitian, analisis data, dan pembahasan, maka dapat disimpulkan bahwa pembelajaran yang menerapkan model pembelajaran learning cycle $5 E$ yang terintegrasi dengan metode problem solving dapat meningkatkan aktivitas belajar dan kemampuan pemecahan masalah peserta didik kelas XI MIA 1 SMA Negeri 
3 Makassar pada materi titrasi dan kesetimbangan larutan dengan merangsang pengetahuan awal yang dimiliki peserta didik, memberikan pengalaman belajar berupa diskusi kelas maupun kelompok, memberikan kesempatan kepada peserta didik untuk bertanya, menjawab, mengungkapkan ide-ide mereka, melatihkan peserta didik pada indikator kemampuan pemecahan masalah, dan mengevaluasinya.

\section{DAFTAR PUSTAKA}

Auliah, Army, dan Supriati. 2009. Penerapan Pembelajaran Siklus Belajar Setting Kooperatif STAD pada Kelas XI IPA 1 SMA Negeri 1 Sugguminasa. Jurnal Chemica Vol. 10 Nomor 1 Juni 2009, 28-35.

Hasanah, Uswatun., Kus Sri Martini, Agung Nugroho Catur Saputro. 2015. Penerapan Metode Problem Solving Terbimbing Untuk Meningkatkan Aktivitas Dan Prestasi Belajar Kimia Pada Materi Pokok Kesetimbangan kelarutan Siswa Kelas Xi Ipa 4 Sma Al Islam 1 Surakarta Tahun Pelajaran 2013/2014. Jurnal Pendidikan Kimia (JPK), Vol. 4 No. 1 Tahun 2015 Program Studi Pendidikan Kimia Universitas Sebelas Maret Hal. 68-73 ISSN 2337-9995.

Nasution, S. 2008. Berbagai Pendekatan dalam Proses Belajar Mengajar. Jakarta: PT. Bumi Aksara.

Palennari, Muhiddin, dan Adnan. 2010. Penerapan Pembelajaran Model Learning Cycle (Siklus Belajar) untuk Meningkatan Aktivitas Belajar Siswa Sekolah Menengah Pertama. Bionature Vol. 11 (1) Hlm: 37-43. April 2010. ISSN: 14114720 .

Permadi, Yudi Putra. 2017. Pengaruh Metode Problem Posing Pada Model Pembelajaran Learning Cycle 5E Terhadap Motivasi dan Kemampuan Pemecahan Masalah Peserta Didik SMA Negeri 1 Liliriaja Kelas XI IPA. [Skripsi]. Makassar: Universitas Negeri Makassar.

Sopian, Yopi Ahmad, Ekasatya Aldila Afriansyah. 2017. Kemampuan Proses Pemecahan Masalah Matematis Siswa Melalui Model Pembelajaran Creative Problem Solving Dan Resource Based Learning (Studi Eksperimen Pada Siswa Kelas X Smk Krija Bhakti Utama Limbangan). Jurnal Elemen Vol. 3 No. 1, Januari 2017, hal. 97 - 107.

Sudarjo. 2016. Penerapan Model Pembelajaran Learning Cycle dalam Upaya Meningkatkan Hasil Belajar Siswa Pada Mata Pelajaran Ekonomi Kelas X.4 SMA Negeri 1 Turatea. [Skripsi]. Makassar: Fakultas Ekonomi Universitas Negeri Makassar.

Sutardi, Irwandi, Taslima, Rahmi Nuraztia. 2015. Peningkatan Aktivitas Belajar SISWA Dan Kemampuan Komunikasi Matematika Untuk Kimia Dengan Model 
Penerapan Model Pembelajaran Learning Cycle 5E yang Terintegrasi dengan Metode Problem Solving

Pembelajaran LEARNING CYCLE 5E DI Kelas XI-Ipa 2 Man Model Singkawang Tahun Pelajaran 2013/2014. Jurnal Kaunia Vol. XI No. 2: 100-109.

Tawil, M, dan Liliasari. 2013. Berpikir Kompoleks dan Implementasinya dalam Pembejaran IPA. Makassar: Badan Penerbit UNM.

Zulfianti. 2016. Pengaruh Tipe Pembelajaran Kooperatif dan Gaya Belajar Terhadap Kemampuan Pemecahan Masalah Peserta Didik Kelas X SMA Wahyu Makassar. [Tesis]. Makassar: Program Pascasarjana Universitas Negeri Makassar. 